Nr 3(66), 2020, s. 133-144

https://doi.org/10.12797/Politeja.17.2020.66.09

\author{
Aleksandra KRUK (D) \\ Uniwersytet Zielonogórski \\ Aleksandra.kruk@wp.pl
}

\title{
MIĘDZYNARODOWE ROLE UNII EUROPEJSKIEJ W WYPOWIEDZIACH JAVIERA SOLANY, CATHERINE ASHTON I FEDERIKI MOGHERINI PODCZAS MONACHIJSKICH KONFERENCJI BEZPIECZEŃST WA W LATACH 2009-2019
}

ABSTRACT European Union's International Role in Statements of Javier Solana, Catherine Ashton and Frederica Mogherini during the Munich Security Conferences in the Years 2009 until 2019

The aim of the article is an analysis of statements of the European union's foreign affairs and security policy high representatives during the Munich Security Conference in years 2009 until 2019. The diplomats' activities resulted from their roles as high representatives, which are programming, initiating action and representing the European Union outside. The Munich Security Conferences were a platform to present activities and stand points concerning contemporary challenges in the field of international security. The conferences contributed to the extension of contacts of the EU from Javier Solana's, Catherine Ashton's and Federica Mogherini's points of view.

Keywords: Munich Security Conference, High Representative of the Union for Foreign Affairs and Security Policy, global power

Słowa kluczowe: Monachijska Konferencja Bezpieczeństwa, wysoki przedstawiciel Unii do spraw zagranicznych i polityki bezpieczeństwa, globalne mocarstwo 


\section{WPROWADZENIE}

Popularne badania ról międzynarodowych, które pozwalają interpretować aktywność bądź pasywność aktorów międzynarodowych, zapoczątkował w latach 70. XX w. Kalevi J. Holsti, który doczekał się wielu kontynuatorów na całym świecie. Wśród polskich badaczy temat ten analizowali m.in. Ziemowit Jacek Pietraś, Justyna Zając i Anna Antczak-Barzan ${ }^{1}$. Badania nad sposobem definiowania międzynarodowych ról Unii Europejskiej (UE) przez Javiera Solanę, Catherine Ashton i Federicę Mogherini podczas Monachijskich Konferencji Bezpieczeństwa prowadzono, wykorzystując metodę krytycznej analizy tekstu oraz metodę porównawczą, które pozwoliły dostrzec ciągłość i zmianę problematyki poruszanej w przemówieniach polityków. Konferencje potraktowano jako studia przypadków, biorąc pod uwagę, że corocznie z inicjatywy aktorów państwowych i niepaństwowych odbywa się wiele światowych spotkań. Wypada jednak zauważyć, że konferencje w Monachium uzyskiwały wysokie oceny think thanków, które organizują wydarzenia związane $\mathrm{z}$ analizą bezpieczeństwa międzynarodowego. Zastosowana cezura badawcza (2009-2019) obejmuje przewodnictwo niemieckiego dyplomaty Wolfganga Ischingera nad konferencjami w Monachium². Przyjęto hipotezę, że Solana, Ashton oraz Mogherini traktowali te konferencje jako ważne forum prezentowania interesów politycznych UE i wykorzystywali udział w nich do prowadzenia polityki zagranicznej. Po wejściu w życie 1 grudnia 2009 r. traktatu lizbońskiego funkcja wysokiego przedstawiciela Unii do spraw zagranicznych i polityki bezpieczeństwa $^{3}$ stała się według Beaty Przybylskiej-Maszner kluczowa ${ }^{4}$, ale już od traktatu amsterdamskiego, od 1999 r., był powoływany wysoki przedstawiciel do spraw wspólnej polityki zagranicznej i bezpieczeństwa 5 . Werner Weidenfeld zaliczył do centralnych reform w traktacie lizbońskim wprowadzenie dwóch twarzy UE: wysokiego przedstawiciela i przewodniczącego Rady Europejskiej. Rezultatem reformy jest według badacza znaczna poprawa widoczności Unii Europejskiej zarówno wśród międzynarodowych partnerów, jak i obywateli oraz umożliwienie identyfikowania się z Europa $q^{6}$.

Aktywność podczas konferencji w Monachium wynikała z realizacji funkcji przypisanych wysokiemu przedstawicielowi: programowania i inicjowania działań, reprezentowania UE na zewnątrz, koordynowania, zarządzania, a także zasięgania opinii

K.J. Holsti, National Role Conceptions in the Study of Foreign Policy, „International Studies Quarterly” 1970, nr 3, s. 233-309.

2 Artykuł przekazano do druku w styczniu $2020 \mathrm{r}$.

3 Dalej: wysoki przedstawiciel.

4 B. Przybylska-Maszner, Spory kompetencyjne wokót urzędu Wysokiego Przedstawiciela Unii Europejskiej do Spraw Zagranicznych i Polityki Bezpieczeństwa, „Studia Europejskie” 2012, nr 2, s. 34.

5 Szerzej zob. Traktat o Unii Europejskiej - tekst skonsolidowany uwzględniajacy zmiany wprowadzone Traktatem z Lizbony, Dz.U. 2004.90.864/30, art. 18.

6 W. Weidenfeld, Europas Seele suchen. Eine Bilanz der europäischen Integration, Baden-Baden 2017, s. $418-419$. 
i realizowania zadań sprawozdawczych i konsultacyjnych ${ }^{7}$ W ciągu badanej w artykule dekady Hiszpan Javier Solana reprezentował UE na konferencji w Monachium raz, w 2009 r., w latach 2010-2014 czyniła to Brytyjka Catherine Ashton, a następnie Włoszka Frederica Mogherini, która w grudniu 2019 r. została zastąpiona przez Hiszpana Josepa Borrella. W artykule przeprowadzono analizę przemówień, które politycy wygłosili w trakcie sesji plenarnych. Badano także upublicznione zapisy wywiadów i rozmów oraz medialne relacje z obecności polityków na konferencji. Ważnym źródłem były dokumenty strategiczne UE, do których politycy odwoływali się w trakcie swoich przemówień. Dodatkowo analizowano dyskurs naukowy na temat międzynarodowych ról, które odgrywa UE, wychodząc z założenia, że Solana, Ashton i Mogherini starali się w Monachium przedstawić ją jako organizację aspirującą do roli mocarstwa (globalny gracz, global player) poprzez wywieranie wpływu na innych aktorów międzynarodowych i wykorzystanie swojego potencjału oraz pozycji na arenie międzynarodowej.

\section{MIĘDZYNARODOWE ROLE UNII EUROPEJSKIEJ}

Politycy dążyli do wzmocnienia wizerunku UE zarówno w państwach członkowskich, jak i poza granicami Unii. Ich wypowiedzi mogły przyczyniać się do kreowania europejskiej tożsamości. Jednak nie wszystkie państwa chcą brać pod uwagę UE jako pretendenta do roli globalnego gracza, przedkładając nad relacje z nią współpracę międzypaństwową (bilateralną), ponieważ między członkami UE były i są widoczne konflikty interesów i stanowisk, np. w kwestiach angażowania się w misje międzynarodowe czy inwestycji energetycznych.

Wielu ekspertów zwraca uwagę na słabości tej organizacji oraz kryzysy, z którymi się boryka. Nicole Gnesotto nazywa Europę konieczną potega, jednak o UE pisze, że jest $w$ stanie destrukcji, ostabiona, podzielona, niewidoczna, niezadowolona, bezsilna ${ }^{8}$. David M. Mccourt i Andrew Glencross są natomiast zdania, że określenie UE jako potęgi dotyczy bardziej roli tej organizacji niż jej statusu. Myślenie w kategoriach ról odnosi się bowiem nie do oceniania Unii w rankingu innych aktorów międzynarodowych, ale do oczekiwań stawianych tej organizacji. Z badań Hedleya Bulla wynika, że od UE oczekuje się: 1) utrzymania równowagi sił między potęgami; 2) zapobiegania kryzysom; 3) zapobiegania wojnom; 4) zachowania lokalnych przewag; 5) ustalania sfer wpływów i interesów; 6) angażowania się w koncert mocarstw9. Zasoby, którymi dysponuje ta organizacja, sprawiają, że może być traktowana jako ważny aktor międzynarodowy, chociaż jej znaczenie gospodarcze ulega osłabieniu ${ }^{10}$. Unia Europejska jest brana pod

T. Dubowski, Wysoki Przedstawiciel Unii ds. Zagranicznych i Polityki Bezpieczeństwa, Białystok 2017, s. 107-148.

$8 \quad$ N. Gnesotto, Przysztość Europy strategicznej, przeł. M. Wodzyńska, Warszawa 2012, s. 142.

9 D.M. Mccourt, A. Glencross, Great Expectations: The EU'S Social Role as a Great Power Manager, „New Perspectives” 2019, Vol. 27, nr 1, s. 22.

10 Z.B. Rudnicki, Zmieniający się światowy uktad sit: zmierzch Zachodu i jego implikacje dla Unii 
uwagę jako strukturalna potęga, która rywalizuje z innymi potęgami posiadającymi zasoby i chcacymi determinować lub wptywać na polityczne, prawne, ekonomiczne, spoteczne lub inne reguty gry ${ }^{11}$. Jej syntetyczna rola globalnego gracza zawiera w sobie także inne: mocarstwa niewojskowego, mocarstwa ekonomicznego, mocarstwa regionalnego, partnera strategicznego, pomostu między państwami bogatymi i biednymi, mediatora, koncyliatora, promotora wartości demokratycznych, praw człowieka i zasad wolnorynkowych, regionalnego integratora ${ }^{12}$, menadżera wielkiego mocarstwa ${ }^{13}, d y$ plomatycznego, odpowiedzialnego za obronność $i$ bezpieczeństwo, strategicznego aktora ${ }^{14}$, smartpower ${ }^{15}$. Wielość głosów na temat roli UE (wypowiadają się o niej m.in. przewodniczący Rady Europejskiej, przewodniczący Parlamentu Europejskiego, przewodniczący Komisji Europejskiej, wysoki przedstawiciel) pozwala obserwować, jak różnorodna i dynamiczna może być debata nad polityką międzynarodową w tej organizacji. Mimo sceptycyzmu i krytycyzmu wobec jej efektów wielu polityków podkreśla znaczenie deliberacji i współpracy jako sposobów na budowanie europejskiej kultury politycznej czy aktywizowanie opinii. W relacjach z innymi aktorami międzynarodowymi UE wskazuje na potrzebę przestrzegania prawa międzynarodowego oraz wartości zawartych w piramidzie Iana Mannersa. Badacz na jej wierzchołku umieścił pokój, podstawę stanowią równość, solidarność społeczna, zrównoważony rozwój i dobre rządzenie, a wnętrze wypełniają wolność, demokracja, prawa człowieka i praworządność. Unia Europejska postuluje współpracę z Paktem Północnoatlantyckim i Organizacją Narodów Zjednoczonych poprzez wdrażanie multilateralizmu ${ }^{16}$. Od lat kształtuje ona swój wizerunek, tj. stworzony w określonym celu obraz odbierany przez opinię publiczna ${ }^{17}$. Autostereotypy $i$ heterostereotypy determinowały od lat postrzeganie funkcji organizacji, a wysoki przedstawiciel może próbować wpływać na dyskurs o jej tożsamości i postrzeganiu, zarówno na zewnątrz, jak i w jej strukturach. Wystąpienia tych organów umożliwiają też ocenę, czy ich deklaracje i działania są spójne z wystąpieniami innych liderów UE.

Europejskiej, [w:] A. Mania i in., Stany Zjednoczone oraz państwa europejskie między globalizacją a regionalizacja, Warszawa 2018, s. 97-118.

11 S. Keukeleire, T. Delreuz, Competing Structural Powers and Challenges for the EU's Structural Foreign Policy, „Global Affairs” 2015, Vol. 1, nr 1, s. 44.

12 A. Antczak, Role międzynarodowe Unii Europejskiej. Aspekty teoretyczne, Warszawa 2012, s. 154-155.

13 D. M. Mccourt, A. Glencross, Great Expectations..., s. 17-42.

14 T. Novotná, The EU as a Global Actor: United We Stand, Divided We Fall, ,Journal of Common Market Studies” 2017, Vol. 55, s. 178; A. Nitszke, Europejska Stużba Dziatań Zewnętrznych - nowa jakość dyplomacji unijnej, „Politeja” 2019, Vol. 15, nr 54, s. 259-260.

15 L. Wojnicz, Misje cywilne Unii Europejskiej w procesie europeizacji ad extra, Toruń 2019, s. 141.

16 A. Antczak, Role międzynarodowe Unii Europejskiej..., s. 46; R. Riedel, Unia Europejska jako aktor stosunków międzynarodowych, [w:] Unia Europejska w XXI wieku. Polityczno-prawna wspólnota interesów, red. tenże, Toruń 2010, s. 239-244; Z.B. Rudnicki, Kryzysy Unii Europejskiej, [w:] Unia Europejska w badaniach interdyscyplinarnych, red. M. Potkańska, L. Wojnicz, D. Rdzanek, Szczecin 2019, s. 21; M. Cichocki, Od funkcjonalnej do substancjalnej europejskiej tożsamości-zmiana podejścia do roli europejskich wartości, „Sprawy Międzynarodowe” 2018, nr 2, s. 53.

17 M. Ryniejska-Kiełdanowicz, Dyplomacja publiczna Unii Europejskiej, Warszawa 2019, s. 40. 


\section{Javier Solana}

Doświadczony lewicowy polityk i dyplomata poza pracą w resortach hiszpańskiej egzekutywy miał w swojej karierze politycznej staż na stanowisku przewodniczącego Paktu Północnoatlantyckiego w latach 1995-1999. Funkcję wysokiego przedstawiciela sprawował w latach 1999-2009. Solana podkreślał, że konferencje monachijskie to miejsce, gdzie decydujacy o międzynarodowym bezpieczeństwie moga się spotykać i otwarcie rozmawiac ${ }^{18}$; miejsce dialogu i wspierania międzynarodowych projektów z zakresu polityki bezpieczeństwa. Podczas konferencji w 2009 r. wysoki przedstawiciel zwrócił uwagę, że objęcie w USA władzy przez administrację nowego prezydenta, Baracka Obamy, wpłynie na dyskusje o bezpieczeństwie międzynarodowym. Wymienił globalne problemy (zmiana klimatu, proliferacja broni, bieda) oraz obszary na świecie, które zagrażają międzynarodowej stabilności (Bliski Wschód, Afryka, Południowa Azja), podkreślając jednocześnie, że UE będzie dążyła do zapewniania sobie bezpieczeństwa poprzez współpracę z USA. Solana zaznaczył, że UE wraz z NATO angażuje się w stabilizowanie sytuacji na Bałkanach. Komentując konflikt między Rosją i Gruzją, zaapelował, by Moskwa przestrzegała prawa międzynarodowego oraz respektowała prawa mniejszych państw. Adam Daniel Rotfeld skomentował, że Solana przypomniał o tym, iż aktorzy państwowi mogą samodzielnie wybierać sojuszników, oraz zakwestionował uprzywilejowane strefy wptywów ${ }^{19}$.

\section{Catherine Ashton}

Należąca do Partii Pracy brytyjska polityk nie posiadała dużego doświadczenia w dyplomacji. W latach 2008 i 2009 była komisarzem UE ds. handlu ${ }^{20}$. Pierwszy raz jako wysoki przedstawiciel Unii do spraw zagranicznych i polityki bezpieczeństwa wystąpiła na konferencji w Monachium w 2010 r. Zaznaczyła wówczas, że traktat lizboński stanowi kamień milowy na drodze do europejskiego bezpieczeństwa. Wyraziła też zadowolenie z utworzenia Europejskiej Służby Działań Zewnętrznych (ESDZ), która miała wzmocnić unijną dyplomację. Jednak Karolina Pomorska i Sophie Vanhoonacker skrytykowały skuteczność Ashton we wdrażaniu ESDZ do działania, chociaż sytuacja międzynarodowa dawała wiele okazji, żeby zintensyfikować jej rolę. Zarówno kryzys strefy euro, jak i początek arabskiej wiosny wymagały koordynacji działań dyplomatycznych pod kierunkiem wysokiej przedstawiciel. Mniej krytycznie wypowiedział się Andrzej Dumała, który docenił działania z wykorzystaniem ESDZ jako zmierzające w kierunku

18 J. Solana, Capacity for Adaption: The Munich Conference and European Security, [w:] Towards Mutual Security. Fifty Years of Munich Security Conference, red. W. Ischinger, Göttingen 2014, s. 199.

19 Address by Javier Solana, EU High Representative for the Common Foreign and Security Policy, to the Munich Security Conference, 7 II 2009, [online] https://www.consilium.europa.eu/uedocs/cms_data/ docs/pressdata/EN/discours/105986.pdf, 18 XI 2019; A.D. Rotfeld, Poszukiwanie strategii, [w:] tenże, Myśli o Rosji... i nie tylko. Eseje i wywiady, Warszawa 2012, s. 152.

20 D. Liszczyk, Bilans pierwszego roku urzędowania wysokiej przedstawiciel UE, „Biuletyn PISM” 2011, nr 16. 
poprawy zarzadzania kryzysowego w $\mathrm{UE}^{21}$. Ashton w Monachium postulowała zbudowanie całościowej strategii bezpieczeństwa dla Unii. Wśród zagrożeń wymieniła państwa upadłe, terroryzm, zorganizowaną przestępczość, proliferację broni masowej zagłady, zagrożenia w cyberprzestrzeni. Wskazała również, że UE musi być przygotowana na zmiany klimatyczne, nielegalne migracje i handel ludźmi, wyzwania energetyczne oraz rywalizację w korzystaniu z naturalnych surowców, i powinna współpracować z innymi organizacjami międzynarodowymi w zakresie zarządzania kryzysowego, polityki rozwojowej, praw człowieka i zmian klimatycznych. Unia Europejska angażuje się na różnych terytoriach poprzez wysyłanie wsparcia, np. współpracuje z ONZ w przywracaniu stabilności po kryzysie wywołanym trzęsieniem ziemi na Haiti, z NATO na Bałkanach, z Unią Afrykańską w Somalii, a z Organizacją Bezpieczeństwa i Współpracy w Europie na Bałkanach i w Gruzji. Obok współpracy z organizacjami Ashton dostrzegła potrzebę współpracy strategicznej UE z państwami: Chinami, Indiami, Republiką Południowej Afryki, Brazylią, Meksykiem i Indonezją, i uznała, że organizacja musi prowadzić aktywną politykę wobec Ukrainy, Gruzji i na Bałkanach. W 2010 r., wbrew krytycznym uwagom niemieckich dziennikarzy i protestom społecznym, wysoka przedstawiciel wyraziła zadowolenie, że podczas konferencji w Monachium odbyło się spotkanie ministra spraw zagranicznych Iranu Manouchehra Mottakiego z dyrektorem Międzynarodowej Agencji Energii Atomowej, Japończykiem Yukiyą Amano. Następca Muhammada el-Baradeia zaznaczył, że dialog z Iranem w sprawie programu atomowego będzie kontynuowany ${ }^{22}$.

Ashton czynnie angażowała się w prace Kwartetu Bliskowschodniego i jej obecność na konferencji w Monachium w 2011 r. także wiązała się z problemem bezpieczeństwa na Bliskim Wschodzie. 5 lutego wysoka przedstawiciel uczestniczyła w spotkaniu Kwartetu Bliskowschodniego wraz z sekretarzem generalnym ONZ Ban Ki-moonem, sekretarz stanu USA Hilary Clinton, przedstawicielem USA ds. procesu pokojowego na Bliskim Wschodzie George'em Mitchellem, ministrem spraw zagranicznych Rosji Siergiejem Ławrowem i byłym premierem Wielkiej Brytanii Tonym Blairem. Rozmowy dotyczyły sytuacji w Egipcie oraz relacji izraelsko-arabskich. Jako rozwiązanie konfliktu między Izraelem a Palestyną podjęto temat istnienia dwóch państw na Ziemi Świętej ${ }^{23}$. Natomiast monachijskie rozmowy na temat Iranu w 2013 r. były jednym

21 Decyzja Rady określająca organizację i zasady funkcjonowania Europejskiej Służby Działań Zewnętrznych, 26 VII 2010, [online] https://pl.vlex.com/vid/decyzja-lipca-zasady-funkcjono wania-215077015, 3 XII 2019; A. Dumała, Europejska Stużba Dziatań Zewnętrznych - analiza pierwszego okresu dziatalności, [w:] A. Kruk, Ministerstwa spraw zagranicznych wobec wyzwań XXI wieku, Łódź 2013, s. 151-173; K. Pomorska, S. Vanhoonacker, Europe as a Global Actor: the (Un)Holy Trinity of Economy, Diplomacy and Security, „Journal of Common Market Studies” 2015, Vol. 53, s. 217.

22 Remarks by HR Catherine Ashton, at the Munich Security Conference, 6 II 2010, [online] https://www. consilium.europa.eu/uedocs/cms_data/docs/pressdata/EN/foraff/112774.pdf, 18 XI 2019; Mottaki: Political Will Exists for Fuel Swap, 7 II 2010, [online] https://www.globalsecurity.org/wmd/library/news/iran/2010/iran-100207-irna01.htm, 21 XI 2019.

23 Middle East Quartet Statement, Munich, 5 II 2011, [online] https://www.consilium.europa.eu/uedocs/cms_data/docs/pressdata/EN/foraff/119200.pdf, 18 XI 2019; EU High Representative Catherine Ashton Chairs Middle East Quartet Ministerial Meeting in Munich, 4 II 2011, [online] https:// 
z etapów na drodze do podpisania w listopadzie 2013 r. Wspólnego planu działania (Joint Plan of Action) między P5 (piątka nuklearnych mocarstw: USA, Rosją, Wielką Brytanią, Francją i Chinami) a Iranem. Uznaje się, że to Catherine Ashton wykazała wiele zdolności dyplomatycznych podczas negocjacji z Mohammadem Dżawadem Zarifem, chociaż na zbliżenie stanowisk wpłynęła również przychylna postawa prezydenta Baracka Obamy wobec objęcia urzędu prezydenta w Iranie przez Hassana Rouhaniego. Zarówno Radosław Fiedler, jak i Wolfgang Ischinger stwierdzili, że osobista rola wysokiej przedstawiciel przyczyniła się do przełamania impasu w unijnych negocjacjach w sprawie pozyskiwania uranu przez $\operatorname{Iran}^{24}$.

\section{Federica Mogherini}

Córka reżysera Flavio Mogheriniego i absolwentka politologii w młodości sympatyzowała z ruchami lewicowymi. W polityce międzynarodowej interesowała się Bliskim Wschodem, napisała pracę magisterską o islamie. W 2008 r. została członkiem włoskiego parlamentu, w którym zajmowała się polityką międzynarodową. Od lutego $2014 \mathrm{r}$. była ministrem spraw zagranicznych w rządzie lidera Partii Demokratycznej Matteo Renziego. 1 listopada 2014 r. Mogherini przejęła funkcję wysokiego przedstawiciela Unii Europejskiej ds. wspólnej polityki zagranicznej i bezpieczeństwa po Ashton, pokonując kandydaturę Bułgarki Kristaliny Georgiewy oraz Belga Karela De Guchta ${ }^{25}$.

Pierwszy raz jako wysoka przedstawiciel Włoszka zabrała głos na konferencji w Monachium w 2015 r., gdzie swoje exposé zaczęła od stwierdzenia: żyjemy w czasach potworów, podczas gdy przełomowy rok 1989 dawał ludziom nadzieję na pozytywne przemiany. Mogherini podkreśliła, że bipolarny w trakcie zimnej wojny świat nie stał się obecnie ani unilateralny, ani multilateralny, gdyż aktualny porządek międzynarodowy kształtuje kompleksowość, konfliktogenność oraz współzależność. Polityk zaznaczyła, że zadaniem UE jest przeciwstawienie się łamaniu prawa międzynarodowego publicznego, w tym siłowej zmianie granic. W tym celu organizacja powinna wykorzystywać narzędzia dyplomacji, takie jak sankcje gospodarcze, a także różne

www.consilium.europa.eu/uedocs/cms_Data/docs/pressdata/EN/foraff/119144.pdf, 18 XI 2019; N. Werkhäuser, Welche Rolle spielt das Nahost-Quartett?, 5 II 2011, [online] https://www.dw.com/ de/welche-rolle-spielt-das-nahost-quartett/a-14818451, 18 XI 2019.

24 Irans Atomprogramm. Neue Verhandlungen möglich, 3 II 2013, [online] https://taz.de/Irans-Atomprogramm/!5074010/, 18 XI 2019; Sicherheitskonferenz in München: „Staatengemeinschaft muss Verantwortung für Syrien wahrnehmen”, „Frankfurter Allgemeine Zeitung” 2013, 2 II; R. Fiedler, Iran and the European Union after the Nuclear Deal, „CES Working Papers” 2018, nr 10, s. 297; W. Ischinger, Welt in Gefahr. Deutschland und Europa in unsicheren Zeiten, Berlin 2018, s. 257; L. Powirska, Granice potencjatu mediacyjnego Unii Europejskiej, „Bezpieczeństwo Narodowe” 2015, nr 3, s. 100.

25 T. Bielecki, Nie taka Mogherini straszna, jak ja maluja, „Gazeta Wyborcza” 2014, 2 IX; J. Panicki, Federica Mogherini - Italy's Scapegoat, „European Voice” 2014, 24 VIII; F. Eder, Harter Kampf um das Amt des EU-Chefdiplomaten, „Welt” 2014, 16 VII, [online] https://www.welt.de/politik/ausland/article130204894/Harter-Kampf-um-das-Amt-des-EU-Chefdiplomaten.html, 16 IX 2019; F. Austermann, The European External Action Service ad its Delegations: a Diplomatic Service of Different Speeds, „Global Affairs” 2015, Vol. 1, nr 1, s. 51. 
formaty negocjacyjne i mediacje. Zadaniem UE jest działanie na rzecz procesów state building, demokratyzacji, reform ekonomicznych i procesów integracyjnych. Mogherini odpowiedziała Ischingerowi, że za największe problemy uważa m.in. sytuację wokół konfliktów na Ukrainie i w Libii. Podkreśliła też potrzebę stworzenia globalnej strategii, gdyż jej zdaniem ograniczanie się do budowania strategii bezpieczeństwa to za mało ${ }^{26}$. Proces negocjowania dokumentu, czyli strategicznej refleksji, oceniała jako tak samo ważny jak efekt końcowy ${ }^{27}$, a strategię bezpieczeństwa UE z 2003 r. interpretowała jako dążenie do bycia globalnym graczem i wyraz globalnych ambicji unijnej klasy politycznej28.

Podczas konferencji monachijskiej w 2016 r. Mogherini uczestniczyła w panelu razem z irańskim ministrem spraw zagranicznych Zarifem, uważanym za jednego z głównych twórców porozumienia w sprawie układu nuklearnego z Iranem, zawartego 14 lipca 2015 r. Stronami porozumienia były UE i P5. Niemiecki przewodniczący konferencji monachijskiej Ischinger podkreślił, że zaangażowanie UE w kwestię polityki nuklearnej Iranu zostało ugruntowane po wejściu w życie traktatu lizbońskiego. Natomiast Mogherini od dawna interesowała się polityką Bliskiego Wschodu i dążyła do uregulowania relacji z Iranem. Porozumienie nuklearne uważała za sukces. Umowa została jednak krytycznie przyjęta przez Izrael, a w 2018 r. Donald Trump się z niej wycofat ${ }^{29}$.

W monachijskim przemówieniu z 18 lutego 2017 r. wysoka przedstawiciel podkreśliła nieodzowność współpracy z NATO i ONZ. Przypomniała, że w ciągu minionych siedmiu lat NATO i UE zrealizowały 42 wspólne projekty, i podkreśliła znaczenie misji cywilnych oraz wojskowych UE. Opowiedziała się także za ponoszeniem kosztów uczestniczenia w globalnym systemie bezpieczeństwa, burden sharing. Mogherini odniosła się do przyjętej w 2016 r. Globalnej strategii ds. polityki zagranicznej i bezpieczeństwa Unii Europejskiej (EU Global Strategy for the Foreign and Security Policy) ${ }^{30}$, przypominając, że w strategii pojawiło się stwierdzenie do przewidzenia nieprzewidzialny (predictable unpredictability). Zaznaczyła, że ma przywilej patrzenia na UE z perspektywy jej partnerów, m.in. Japonii i Kanady, i może wypowiedzieć się na temat wizerunku organizacji wśród innych aktorów międzynarodowych, lepszego niż wewnątrz UE. Według wysokiej przedstawiciel UE potrzebuje zarówno miękkiej, jak i twardej siły. Mogherini łączyła multilateralizm z wolnym handlem, fair trade,

26 Speech by HRVP Federica Mogherini at the Munich Security Conference, [online] https://www.youtube.com/watch?v=gi_KJq3zl0w, 16 IX 2019.

27 T. Novotná, The EU as a Global Actor..., s. 180.

28 P. Żurawski vel Grajewski, Bezpieczeństwo międzynarodowe. Wymiar militarny, Warszawa 2012, s. 269, Stosunki Międzynarodowe.

29 V. Lamprecht, L.M. Ullrich, Perfekter Sturm oder neuer Kalter Krieg? Ein Berichtüber die 52. Münchner Sicherheitskonferenz, „Zeitschrift für Außen und Sicherheitspolitik” 2016, Vol. 9, nr 2, s. 26; W. Ischinger, Welt in Gefahr..., s. 257.

30 Wspólna wizja, wspólne dziatanie: Silniejsza Europa. Globalna strategia na rzecz polityki zagranicznej i bezpieczeństwa Unii Europejskiej, [online] http://eeas.europa.eu/archives/docs/top_stories/pdf/ eugs_pl_.pdf, 16 IX 2019. 
rozwojem ekonomicznym oraz celami zrównoważonego rozwoju, i zaznaczyła, że UE to największy donator pomocy humanitarnej, a także potęga dyplomatyczna i polityczna. Opowiedziała się za inwestowaniem w silne społeczeństwo, którego wyznaczniki to: stabilność, odporność, prawa człowieka, demokracja, dobre zarządzanie, edukacja, jak również za inwestowaniem w dobre relacje z państwami w ramach silnego systemu ONZ (od Unii Afrykańskiej do Ligi Państw Arabskich). Zaznaczyła, że niestabilność Ukrainy powoduje niestabilność regionu i rozmawiała o konflikcie w tym kraju z wiceprezydentem Mikiem Pence'em oraz kanclerz Angelą Merkel. Zaproponowała rozważenie poszerzenia formatu normandzkiego (Francja, Niemcy, Rosja, Ukraina) o USA i wyraziła poparcie dla porozumienia z Mińska. Współpracując z prezydentem Ukrainy Petro Poroszenką oraz premierem Vołodymyrem Hrojsmanem i postulowała dalsze sankcje wobec Rosji ${ }^{31}$.

W 2019 r. na konferencję nie przybyli prezydent Francji Emmanuel Macron i premier Izraela Binjamin Netanjahu. Natomiast Mogherini pojawiła się na konferencji w Monachium 15 lutego, chociaż nie przyjęła zaproszenia na zorganizowaną 13 i 14 lutego 2019 r. w Warszawie konferencję ds. Bliskiego Wschodu. Razem z Jensem Stoltenbergiem i Heiko Maasem wzięła udział w panelu prowadzonym przez dyrektor włoskiego Instytutu Spraw Międzynarodowych Nathalie Tocci. Wysoka przedstawiciel ponownie zaznaczyła, że UE potrzebuje siły - zarówno twardej (obrona), jak i miękkiej (handel). Poparła wizję multilateralizmu postulowaną przez Maasa, tzn. forum otwartego dla innych państw i organizacji międzynarodowych, które znajdą porozumienie na temat przestrzeganych wartości, norm i umów międzynarodowych. Pomysł budowania sojuszu multilateralistów, złożonego z UE, Kanady, Japonii, Australii i innych członków koalicji chętnych, uważała za potrzebny. Mogherini odniosła się także do problemu great power competition w polityce globalnej, zaznaczając, że Europejczycy w przeszłości wybierali nie great power competition, ale cooperative power ${ }^{32}$. Omawiając Munich Security Report, wysoka przedstawiciel zaznaczyła, że państwa europejskie są tam określane jako middle powers - jej zdaniem zbyt ogólnie, bo w UE występują również małe państwa. Ponadto wymieniła wiodące konflikty: w Libii, Syrii, na Ukrainie i w Jemenie. Za osiągnięcie UE uznała stałą współpracę strukturalną (permament structual cooperation, PESCO). Zwróciła też uwagę na rolę Europejskiego Funduszu Obronnego, na który w latach 2020-2027 przewidziano 13 bln euro. Na koniec podkreśliła potrzebę współpracy z grupą G5 Sahel (Mauretania, Mali, Burkina Faso, Niger, Czad) ${ }^{33}$.

31 Speech by Federica Mogherini at the Munich Security Conference, 18 II 2017, [online] https://eeas.europa.eu/headquarters/headquarters-homepage_en/20832/Speech $\% 20$ by $\% 20$ Federica $\% 20$ Mogherini\%20at\%20the\%20Munich\%20Security\%20Conference, 16 IX 2019.

32 M. Kolb, P.-A. Krüger, Von der Leyen: Unsere Partnerschaft beruht nicht auf Dominanz, „Süddeutsche Zeitung" 2019, 15 II.

33 Speech by High Representative/Vice-President Federica Mogherini at the Munich Security Conference, 15 II 2019, [online] https://eeas.europa.eu/headquarters/headquarters-homepage_en/58232/ Speech\%20by\%20High\%20Representative/Vice-President\%20Federica\%20Mogherini\%20at\%20 the\%20Munich\%20Security\%20Conference, 16 IX 2019. 


\section{PODSUMOWANIE}

Przemówienia Solany, Ashton i Mogherini miały charakter dokumentów roboczych i nie stały się tak popularne, jak mowy Winstona Churchilla czy innych mężów stanu. Politycy wykorzystywali czas spędzany w Monachium, aby negocjować i załatwiać sprawy należące do ich kompetencji, występując np. w roli mówcy czy mediatora, oraz definiować zagrożenia. Można rozważać, na ile ich wypowiedzi wpłynęły na budowanie pozytywnego wizerunku UE na arenie międzynarodowej, kształtowanie europejskiej tożsamości czy opinię publiczną. Spośród deklarowanych ról dominowało przedstawianie organizacji jako globalnego gracza, otwartego na prowadzenie polityki multilateralnej i dążącego do działania w ramach partnerstw strategicznych. Politycy w swoich przemówieniach podkreślali potrzebę uwzględniania różnych aspektów bezpieczeństwa międzynarodowego, np. ekologicznego i humanitarnego. Postulowali też kontynuację współpracy transatlantyckiej, mimo istniejących rozbieżności (m.in. polityki wobec Iranu).

\section{BIBLIOGRAFIA}

Address by Javier Solana, EU High Representative for the Common Foreign and Security Policy, to the Munich Security Conference, 7 II 2009, [online] https://www.consilium.europa.eu/ uedocs/cms_data/docs/pressdata/EN/discours/105986.pdf.

Antczak A., Role międzynarodowe Unii Europejskiej. Aspekty teoretyczne, Warszawa 2012.

Austermann F., The European External Action Service ad its Delegations: a Diplomatic Service of Different Speeds, „Global Affairs” 2015, Vol. 1, nr 1, https://doi.org/10.1080/23340460.2 015.986700 .

Bielecki T., Nie taka Mogherini straszna, jak ja maluja, „Gazeta Wyborcza” 2014, 2 IX.

Cichocki M., Od funkcjonalnej do substancjalnej europejskiej tożsamości - zmiana podejścia do roli europejskich wartości, „Sprawy Międzynarodowe” 2018, nr 2.

Decyzja Rady określajaca organizacje i zasady funkcjonowania Europejskiej Stużby Dziatań Zewnętrznych, 26 VII 2010, [online] https://pl.vlex.com/vid/decyzja-lipca-zasadyfunkcjonowania-215077015.

Dubowski T., Wysoki Przedstawiciel Unii ds. Zagranicznych i Polityki Bezpieczeństwa, Białystok 2017.

Dumała A., Europejska Stużba Dziatań Zewnętrznych - analiza pierwszego okresu dziatalności, [w:] Ministerstwa spraw zagranicznych wobec wyzwań XXI wieku, red. A. Kruk, Łódź 2013.

Eder F., Harter Kampf um das Amt des EU-Chefdiplomaten, „Welt” 2014, 16 VII, [online] https://www.welt.de/politik/ausland/article130204894/Harter-Kampf-um-das-Amt-des-EU-Chefdiplomaten.html.

EU High Representative Catherine Ashton chairs Middle East Quartet Ministerial meeting in Munich, 4 II 2011, [online] https://www.consilium.europa.eu/uedocs/cms_Data/docs/pressdata/EN/foraff/119144.pdf. 
Fiedler R., Iran and the European Union after the Nuclear Deal, „CES Working Papers” 2018, nr 10.

Gnesotto N., Przysztość Europy strategicznej, przeł. M. Wodzyńska, Warszawa 2012.

Holsti K.J., National Role Conceptions in the Study of Foreign Policy, „International Studies Quarterly" 1970, nr 3.

Irans Atomprogramm. Neue Verhandlungen möglich, 3 II 2013, [online] https://taz.de/ Irans-Atomprogramm/!5074010/.

Ischinger W., Welt in Gefahr. Deutschland und Europa in unsicheren Zeiten, Berlin 2018.

Keukeleire S., Delreux T., Competing Structural Powers and Challenges for the EU's Structural Foreign Policy, „Global Affairs” 2015, Vol. 1, nr 1, https://doi.org/10.1080/23340460.20 15.983730.

Kolb M., Krüger P.-A., Von der Leyen: „Unsere Partnerschaft berubt nicht auf Dominanz”, „Süddeutsche Zeitung" 2019, 15 II.

Lamprecht V., Ullrich L.M., Perfekter Sturm oder neuer Kalter Krieg? Ein Bericht über die 52. Münchner Sicherheitskonferenz, „Zeitschrift für Außen- und Sicherheitspolitik” 2016, Vol. 9, nr 2, https://doi.org/10.1007/s12399-016-0566-0.

Liszczyk D., Bilans pierwszego roku urzędowania wysokiej przedstawiciel UE, „Biuletyn PISM” 2011, nr 16.

Mccourt D.M., Glencross A., Great Expectations: The EU's Social Role as a Great Power Manager, „New Perspectives” 2019, Vol. 27, nr 1, https://doi.org/10.1177/2336825x1902700102.

Middle East Quartet Statement, Munich, 5 II 2011, [online] https://www.consilium.europa.eu/ uedocs/cms_data/docs/pressdata/EN/foraff/119200.pdf.

Mottaki: Political Will Exists for Fuel Swap, 7 II 2010, [online] https://www.globalsecurity.org/ wmd/library/news/iran/2010/iran-100207-irna01.html.

Nitszke A., Europejska Stużba Dziatań Zewnętrznych - nowa jakość dyplomacji unijnej, „Politeja” 2019, Vol. 15, nr 54, https://doi.org/10.12797/Politeja.15.2018.54.17.

Novotná T., The EU as a Global Actor: United We Stand, Divided We Fall, „Journal of Common Market Studies” 2017, Vol. 55, https://doi.org/10.1111/jcms.12601.

Panicki J., Federica Mogherini - Italy's Scapegoat, „European Voice” 2014, 24 VIII.

PMspeech at Munich Security Conference, 17 II 2018, [online] https://www.gov.uk/government/ speeches/pm-speech-at-munich-security-conference-17-february-2018.

Pomorska K., Vanhoonacker S., Europe as a Global Actor: the (Un)Holy Trinity of Economy, Diplomacy and Security, "Journal of Common Market Studies” 2015, Vol. 53, https://doi. org/10.1111/jcms.12272.

Powirska L., Granice potencjatu mediacyjnego Unii Europejskiej, „Bezpieczeństwo Narodowe” 2015, nr 3 .

Przybylska-Maszner B., Spory kompetencyjne wokót urzędu Wysokiego Przedstawiciela Unii Europejskiej do Spraw Zagranicznych i Polityki Bezpieczeństwa, „Studia Europejskie” 2012, nr 2.

Remarks by HR Catherine Ashton, at the Munich Security Conference, 6 II 2010, [online] https:// www.consilium.europa.eu/uedocs/cms_data/docs/pressdata/EN/foraff/112774.pdf.

Riedel R., Unia Europejska jako aktor stosunków międzynarodowych, [w:] Unia Europejska w XXI wieku. Polityczno-prawna wspólnota interesów, red. R. Riedel, Toruń 2010. 
Rotfeld A.D., Poszukiwanie strategii, [w:] A.D. Rotfeld, Myśli o Rosji... i nie tylko. Eseje i wywia$d y$, Warszawa 2012.

Rudnicki Z.B., Kryzysy Unii Europejskiej, [w:] Unia Europejska w badaniach interdyscyplinarnych, red. M. Potkańska, L. Wojnicz, D. Rdzanek, Szczecin 2019.

Rudnicki Z.B., Zmieniajacy się światowy uktad sit: zmierzch Zachodu i jego implikacje dla Unii Europejskiej, [w:] A. Mania [i in.], Stany Zjednoczone oraz państwa europejskie między globalizacja a regionalizacja, Warszawa 2018.

Ryniejska-Kiełdanowicz M., Dyplomacja publiczna Unii Europejskiej, Warszawa 2019.

Sicherheitskonferenz in München: „Staatengemeinschaft muss Verantwortung für Syrien wahrnehmen”, „Frankfurter Allgemeine Zeitung” 2013, 2 II.

Solana J., Capacity for Adaption: The Munich Conference and European Security, [w:] Towards Mutual Security. Fifty Years of Munich Security Conference, red. W. Ischinger, Göttingen 2014.

Speech by Federica Mogherini at the Munich Security Conference, 18 II 2017, [online] https:// eeas.europa.eu/headquarters/headquarters-homepage_en/20832/Speech\%20by\%20 Federica\%20Mogherini\%20at\%20the\%20Munich\%20Security\%20Conference.

Speech by High Representative/Vice-President Federica Mogherini at the Munich Security Conference, 15 II 2019, [online] https://eeas.europa.eu/headquarters/headquarters-homepage_ en/58232/Speech\%20by\%20High\%20Representative/Vice-President\%20Federica\%20 Mogherini\%20at\%20the\%20Munich\%20Security\%20Conference.

Speech by HRVP Federica Mogherini at the Munich Security Conference, [online] https://www. youtube.com/watch?v=gi_KJq3zl0w.

Traktat o Unii Europejskiej - tekst skonsolidowany uwzgledniajacy zmiany wprowadzone Traktatem z Lizbony, Dz.U. 2004.90.864/30.

Weidenfeld W., Europas Seele suchen. Eine Bilanz der europäischen Integration, Baden-Baden 2017.

Werkhäuser N., Welche Rolle spielt das Nahost-Quartett?, 5 II 2011, [online] https://www. dw.com/de/welche-rolle-spielt-das-nahost-quartett/a-14818451.

Wojnicz L., Misje cywilne Unii Europejskiej w procesie europeizacji ad extra, Toruń 2019.

Wspólna wizja, wspólne dziatanie: Silniejsza Europa. Globalna strategia na rzecz polityki zagranicznej i bezpieczeństwa Unii Europejskiej, [online] http://eeas.europa.eu/archives/docs/ top_stories/pdf/eugs_pl_.pdf.

Zurawski vel Grajewski P., Bezpieczeństwo międzynarodowe. Wymiar militarny, Warszawa 2012, Stosunki Międzynarodowe.

Dr hab. Aleksandra KRUK - doktor habilitowany nauk społecznych w zakresie nauk o polityce, zatrudniona w Instytucie Nauk Politycznych i Administracji Uniwersytetu Zielonogórskiego, prowadzi badania niemcoznawcze i międzynarodowe. 